\title{
THE IMPACT OF INFORMATION TECHNOLOGY ON EFL TEACHING IN INDONESIA
}

\author{
Rosmaladewi \\ rosmaladewi@yahoo.com \\ Politeknik Pertanian Negeri Pangkep \\ Amirullah Abduh \\ amirullah@unm.ac.id \\ Universitas Negeri Makassar
}

\begin{abstract}
This study observes the impact of information and communication technology (ICT) on English as a foreign language (EFL) teaching in secondary school focuses on the culture of teachers in Indonesia in 2007 2012. Through an observation on the ICT program in teaching English in Indonesia and an analysis of the theory of the culture of teaching, it evidences that the application of ICT in teaching EFL has influenced the teachers' cultures at schools. It confirms that the use of the internet and World Wide Web as well as social media has strengthened the four culture of teaching in Indonesia; either individualism, balkanization, collaborative, or contrive collegiality. It changes the way of teachers plan teaching materials, perform their teaching in class, and the way they interact with other teachers and students. However, some challenges facing ICT in Indonesia should be solved. Through this analysis, conclusion and some recommendation are presented at the end of this report.
\end{abstract}

Keywords: EFL Teaching, ICT in ELT, Secondary School 


\section{INTRODUCTION}

It is inevitable that the use of information and communication technology (ICT) makes national borders indistinct through interaction and information sharing world widely. According to Ali (2004), in the era of globalization what happens in one country will bring impacts or influence, positive and/ or negative, to other countries. Indonesia is one of developing countries that set serious concern in the use of ICT to connect with world outside of the nation since 1999 to support official activities (Tim Koordinasi Telematika Indonesia, 2000).In addition, the Indonesian Government has formulated ICT as one of national programs under the presidential instruction. This report analyses the impact of ICT on English as Foreign Language (EFL)teaching in Indonesia in order to improve teachers' performance. The analysis is limited to the culture ofteaching EFL in secondary schools between 2007 and 2012. It begins with overview of EFL teaching and ICT program in Indonesia, then impact of ICT on education and culture of EFL teaching in Indonesia, and challenges facing ICT in Indonesia. This report is closed by presenting conclusion and recommendations.

\section{METHOD}

This study employs a literary research where this study reports the impact of information and communication technology (ICT) on English as a foreign language (EFL) teaching in secondary school focusing on the culture of teachers in Indonesia during 2007 - 2012. This study observes on the ICT program in teaching English in Indonesia and an analysis of the theory of the culture of teaching.

\section{FINDINGS}

\section{Overview of EFL Teaching and ICT Program in Indonesia}

English is considered as a foreign language in Indonesia and it is taught as a compulsory subject from junior secondary schools. In addition, it is a core subject at the first semester in university. Furthermore, ICT program is set to succeed teaching and learning process throughout the nation.

\section{Teaching English approach in Indonesia}

According to the Department of Education and Culture (1994), Indonesia has applied several teaching approaches in order to improve the quality of teaching English and follow the trend of teaching English globally. Those approaches can be seen from the chart below. 


\begin{tabular}{|l|c|l|}
\hline No & Period & \multicolumn{1}{|c|}{ Teaching Approach } \\
\hline 1. & $1946-1958$ & Grammatical Teaching Approach \\
\hline 2. & $1958-1964$ & The audio- lingual method. \\
\hline 3. & $1964-1984$ & Structural approach. \\
\hline 4. & $1984-1994$ & Communicative approach. \\
\hline 5. & 1994- 2004 & Communicative with meaningful approach. \\
\hline 6. & $2004-$ now & Competency based approach. \\
\hline
\end{tabular}

Figure 1. the record of teaching approaches in Indonesia (Department of Education and Culture, (2004).

It can be seen from the chart that Indonesia has practiced various teaching approaches. It began with the introduction of GTM (Grammar Translation Method) from 1946 to 1958 . The use of ICT like tape recorder and cassette was begun when Indonesia applied the Audio- lingual method in the period of 1958 - 1964. In this era, listening comprehension was a focused. There were many teachers training throughout the nation on how to utilize the infrastructure related to the Audio. This is followed by structural approach during 19641984. In the next decade, 1984- 1994, communicative approach was a concerned. However, since 2004, there were demands on IELTS (International English Language Testing System) score as a requirement to study in overseas. That is why since that period competency-based approach has been considered as the best teaching approach.

\section{ICT program on EFL Teaching in Indonesia}

The Indonesian government has put a great concern to the ICT agenda for the development of education. It is set under the presidential instruction No. 6/ 2001(E-Learning Tim, 2012). In addition, Firman \& Tola, (2008) describe that in 2008 the government launched Jardiknas (National education network) agenda as a" backbone connection for education". Furthermore, Ali (2004) says that to realize a five year action plan of the e-Learning program on education 2001-2005, telematika pendidikan (the education telematics team) is order to succeed the programs that can be seen on the table below.

\begin{tabular}{|r|l|l|}
\hline \multirow{2}{*}{ No } & \multicolumn{2}{|c|}{ ICT Programs in Indonesia } \\
\cline { 2 - 3 } & \multicolumn{1}{|c|}{$\mathbf{2 0 0 1 - 2 0 0 5}$} & \multicolumn{1}{c|}{ 2008- 2012 } \\
\hline 1. & $\begin{array}{l}\text { ICT grant for 174 schools in big } \\
\text { cities. }\end{array}$ & $\begin{array}{l}\text { Prepare master plan for ICT } \\
\text { human resources. }\end{array}$ \\
\hline
\end{tabular}




\begin{tabular}{|r|l|l|}
\hline 2. & Wide Area Network for schools & Develop ICT curricula. \\
\hline 3. & ICT for vocational education. & Use ICT learning tools in schools \\
\hline 4. & $\begin{array}{l}\text { Internet connection for } 2000 \\
\text { secondary schools. }\end{array}$ & $\begin{array}{l}\text { Establish the related-education } \\
\text { programs. }\end{array}$ \\
\hline 5. & $\begin{array}{l}\text { E-dukasi. ( } \text { www.e-dukasi.net) } \text { to } \\
\text { provide internet- based learning } \\
\text { material for secondary school } \\
\text { students }\end{array}$ & $\begin{array}{l}\text { Facilitate the use of internet for } \\
\text { efficient teaching-learning process, } \\
\text { digital library network, and } \\
\text { computer assisted instruction } \\
\text { (CAI) learning }\end{array}$ \\
\hline
\end{tabular}

Figure 2. ICT program on Education in Indonesia. (Firman \& Tola, 2008; ELearning Tim, 2012).

The chart shows the comparison of the two periods of the ICT program in Indonesia, which are the beginning period of the application of IT and the most recent agenda of the IT on education. During 2001-2005 the agendas were focused on providing basic infrastructure by allocating IT grant for 174 schools as initial program in big cities, and the accessibility of the internet connection for 2000 secondary schools. The government provides internet- based learning material that can be accessed throughout Indonesia. In comparison, in the most recent programs, during 2008-2012, the platforms focused on preparing master plan for ICT human resources; Developing ICT curricula, teaching and school services were demanded, not only in the classrooms but also in the library and other schools' services.

\section{The Impact of Education and Culture of Teaching EFL in Indonesia}

Thrope (1984) says that this hyperconnected world brings major impacts on education. On the other words, the existence of ICT program on education influences the culture of teaching in Indonesia, because it alters the way of teachers plan their teaching materials, perform teaching in classrooms, and how they communicate with others. Hargreaves(1992) says that it change the social life of its community which is known as culture of teaching; as the beliefs, value, habits, and assumed ways of doing things among communities who have had experience to deal with similar demands and problems for some periods of time, formally of informally. He divides culture of teaching into four forms. 


\section{Individualism}

Hargreaves (1992) states that most teachers still teach in closed doors and isolated environment of their own classroom. In an interview with a teacher of English from Indonesia, he (2012) explains that ICT such as Google academic, Wikipedia, and other providers help him work efficiently without any help from other teachers. He says that the Internet provides limitless sources of information for teaching indifferent ranges from teaching methods, games, lesson planning and activities that are available fee free. He also reveals that the online materials and teaching techniques can be quickly downloaded and directly presented from mobile phone or computer while he is teaching in the classroom.

\section{Balkanization}

Some teachers prefer to closely to their certain groups rather than with all teachers in a school as a whole. Hargreaves (1992) describes that teacher in this form of culture made up of separate and sometimes competing groups because they attach their loyalties and identities to their groups where they spend time most regularly. By utilizing the ICT, teachers communicate even from the distance with their particular groups. He (1994) describes that this culture leads to indifference and conflict between groups.

The teacher in the interview (2012) says that in certain issue he doesn't involve teachers except those who are close to. He states "We have mailing list where we can discuss formal or informal topics, we don't involve other teachers that we don't really close emotionally".

\section{Collaborative culture}

Some teachers tend to interact and work in their groups to share teaching materials. The use of e-mail group, blog, SMS group is common to teachers. Thang \& Wong (2010) evidence that most English language teachers Indonesia use the internet sources in the classrooms and has brought significant change to the way of teachers 
and learners' interaction. The conversion of computer game into learning tools has also revolutionized learning. Hargreaves (1992) explains that teachers who have collaborative culture are more united than divided. There are routine help, support, trust and openness in the teachers' daily activities. Hargreaves (1994) also points out that in this form of culture; teachers tend to be voluntary, developmentoriented, pervasive across time and space. The Indonesian teacher explains:

"We share our experiences in dealing with the constraints of ICT like problems of the Internet connection. The other thing we share is that how to search materials from the internet. We always use Yahoo Messenger and SMS to communicate easily and cheaper"

It seems that collaborative culture is more suitable in modern organization.

\section{Contrived collegiality}

Most of schools demand their teachers and staffs to work collaboratively without attention to teachers' personality and experience. It is characterized by a set of formal, specific bureaucratic procedure, formally schedule meetings and clear job descriptions and training programs. Hargreaves (1994) illustrates that in this culture, teachers are administratively regulated, compulsory, and implemented oriented. Teachers are demanded by the leader to work collaboratively with others, senior and or fresh teachers. There is no reason to avoid bureaucratic meeting because the leader uses ICT like group e-mail or school blog to spread clear job description of the teachers.

In the interview, the teacher explains if he works based on the school structural level. They are divided into some groups to work collaboratively; no matter they are close emotionally or not. To avoid numerous meeting, they use online discussion such as group email, YM, or SMS group. He states "The best way to communicate with teachers that I am not really closed is email group and group SMS we meet only at the beginning and to finalize the discussion".

\section{Challenges Facing ICT in Indonesia}

The application of new programs always leads to difficulties and so needs evaluation for the improvement. The difficulties also occur in the integration of ICT program in education Indonesia. Thang \& Wong (2010) argue that barriers that occur are related accessibility and facilities. While Firman \& Tola ( 2008) state that 
constraints in the implementation of e- learning at school level are lack of ICT equipment and infrastructure including telephone line and electricity supply, unavailability of skillful personnel to manage ICT equipment.

In addition, Insead (2012) mentions that the first-order barrier of technology use in the classrooms is external factors, such as lack of adequate access, time, training and institutional support. While the second-order barrier of technology includes teachers' personal and fundamental beliefs such as teachers' pedagogical beliefs, technology beliefs, and willingness to change. Tsai \& Chai (2012) continue describing that what is considered as the third-order barrier of technology is the lack of design thinking by teachers.

\section{CONCLUSION}

The application of IT on education has brought positive impacts on the culture of teaching English as a Foreign Language (EFL) in secondary schools in Indonesia. The use of the internet and World Wide Web and or social media help English teachers to plan their teaching materials, improve their teaching performance in class, and develop their existence knowledge.

This report has shown that the familiarity of EFL teachers in using IT influences the way teachers communicate and interact with other teachers and students individually and collectively. It changes the form of culture of teaching either individualism, balkanization, collaborative culture, or contrives collegiality.

In order to improve the quality of teaching performance of EFL teaching in secondary schools in Indonesia, the government is recommended to increase the budget allocated to ICT program especially in the availability of infrastructure, introduction to ICT programs related to teaching English skills, training and administrative support related to ICT.

\section{REFERENCES}

Ali, M. (2004) E- Learning in Indonesian Education System, Viewed November 14,2012 http://digilib.umm.ac.id/files/disk1/308/iptummpp-.pdf

Arham, M., Akrab, A.H. (2018), Delving into Delving into Content Lecturers' Teaching Capability in Content Language Integrated Learning (CLIL) at an Indonesian University, Asian ESP Journal, Vol. 14 No. 7.2 (2018). 
Department of Education and Culture (2004) English Language Curriculum, Depdikbud, Jakarta.

E-learning Tim (2012) Pembelajaran Elektronik sebagai salah satu alternatif kegiatanpembelajaran ( E- Learning as one of alternatives in teaching and learning activities)Viewed November 16,,2012 <http://www.depdiknas.go.id.>

Firman, H \& Tola, B ( 2008) The Future of Schooling in Indonesia. CICE

Hiroshima University, Journal of International Cooperation in Education, Vol.11 No.1 (2008). Viewed November 23,2012 http://home.hiroshima/u.ac.jp.cice/11-1Firman.Tola.pdf

Hargreaves, A. (1992), 'Cultures of Teaching; A Focus for Change', in Hargreaves, A. \&Fullan, M (Eds) Understanding Teacher

Development, Cassell Villiers House, London.

Hargreaves, A. (1994), 'Culture', in Hargreaves, A. Changing Teachers,

Changing Times; teachers' work and culture in the postmodern age, Cassell Villiers House, London.

INSEAD: The Business School for the world. ( 2012) The Global Information Technology Report 2012Viewed November 21,2012 http://www3.weforum.org/docs/Global.IT.Report.2012.pdf

Hamzah, A (2009)Evaluasi Kesesuaian Model keperilakuan dalam Penggunaan Teknology Sistem Informasi di Indonesia. ( An Evaluation to Behavior in relation with Information Technology System in Indonesia). Viewed November 14,2012<HttpWWwJournalUiiAcId/1020.pdf>

Thrope, P (1984) The impact of New Information Technology in the Developing Counties' Viewed November 21,2012<http:// infolac2.ucol.mx.documentos/pdf>

Tim Koordinasi Telematika Indonesia (2000). Viewed November 28, 2012 <http://ejournal.narotama.id/files/Kerangka/20Teknolog/20Informasi.Nasi onal.pdf $>$

Tsai,C,C \& ChaiC,S (2012), 'The Third order barrier for technology integration instruction: implications for teachers education Viewed November 21, 2012.<'http:// digilib.umm.ac.id//files/disk1/308/iptummpp-.pdf> 